\title{
CONHECENDO O CURSO DE LICENCIATURA EM QUÍMICA ATRAVÉS DE VISITA GUIADA: UMA FORMA DE DESPERTAR O INTERESSE DO ESTUDANTE
}

\author{
Apresentação: Relato de Experiência \\ Maria Tatiana da Silva Santos ${ }^{1}$; Cíntia de Abreu Arruda²; João Thailan dos Santos Sousa ${ }^{3}$; Leila \\ Barbosa $^{4}$ Kilma da Silva Lima Viana ${ }^{5}$
}

\section{Introdução}

A visita guiada faz parte das atividades desenvolvidas pelo Programa Internacional Despertando Vocações Para as Licenciaturas (PDVL) que tem por objetivo geral, desenvolver ações que auxiliem no despertar do interesse para os cursos de Licenciatura, através da articulação de atividades de ensino, pesquisa e extensão e da troca de saberes entre a Academia e a Escola Básica, tendo como foco a formação do professor e as tecnologias educacionais, utilizando-se do formato de rede de Cooperação Internacional.

Pesquisas realizadas pelo (Brasil/Mec/Inep,2009) mostrou que a disciplina de Química lecionada por profissionais formados na área corresponde a $38,2 \%$, enquanto que $17,4 \%$ são profissionais de áreas afins, 5,5\% da área de pedagogia e 38,9\% profissionais de outras áreas. E, esse fato, se torna cada vez mais alarmante, visto que, um professor que não possui formação específica na área que atua, não possui total domínio para mediar o conhecimento de forma que a aprendizagem mais significativa e a carreira docente mais atraente.

Através da visita guiada, os estudantes do ensino médio têm a oportunidade de conhecer melhor o curso de Licenciatura em Química, participando de visita a todos os setores da Instituição, além disso, presenciando palestras motivadoras sobre a carreira docente e atividades como, por exemplo, o show da Química. Nessa perspectiva, como salienta Viana (2016), para que o estudante desperte o interesse pela área, faz-se necessário que conheça a mesma, para, assim, desmistificá-la, superando o medo do novo.

\section{Relato de Experiência}

A visita guiada foi organizada pelos Licenciandos em Química do IFPE - Campus Vitória e participantes do PDVL, para os estudantes voluntários do $1^{\circ}$ ano da Escola de Referência em Ensino Médio Dias Cardoso, escola estaparticipante das ações do Programa.As atividades foram desenvolvidas da seguinte maneira:

Ao chegarem no Campus pela parte da manhã os estudantes foram levados para o mini auditório onde ocorreu a acolhida por meio da apresentação do programa e foram realizadas dinâmicas para aproximar os estudantes convidados aos Licenciandos. E,logo após, seguimos para conhecer os departamentos da Instituição, dentre eles: biblioteca, sala de coordenação, secretaria, sala de informática, auditório, laboratórios (Química, Físico-Química, Solos) e em cada

\footnotetext{
${ }^{1}$ Licenciatura em Química, IFPE - Campus Vitória, mariatatiana015@hotmail.com

${ }^{2}$ Licenciatura em Química, IFPE - Campus Vitória, cintiaarruda@outlook.com

${ }^{3}$ Ensino Médio ( $2^{\circ}$ ano), EREM - Dias Cardoso, carmunrro@hotmail.com

${ }^{4}$ Ensino Médio ( $2^{\circ}$ ano), EREM - Dias Cardoso

${ }^{5}$ Professora do Curso de Licenciatura em Química, IFPE - Campus Vitória, kilma.viana@vitoria.ifpe.edu.br
} 
departamento desse, pedíamos para que um responsável apresentasse um pouco sobre o seu local de trabalho.Após essa visita, houve uma pausa para o almoço, disponibilizado pelo refeitório da instituição e depois disso os alunos tiveram um intervalo de vinte (20) minutos para o descanso do almoço.

Na parte da tarde, realizamos a "Química Espetacular", com atividades lúdicas de jogos e experimentação, abordando assuntos Químicos de forma contextualizada para chamar a atenção dos estudantes, destacando que a Química está presente em todos os lugares e pode ser trabalhada de formas variadas.

No final perguntamos o que os estudantes acharam da visita guiada e percebemos que a maioria dos estudantes gostaram da vivência, pois relataram que as atividades realizadas foram importantes, visto que, aprenderam muitas coisas que não sabiam de uma forma divertida e ao mesmo tempo inesquecível.

Dessa forma percebemos o quanto essas atividades foram significativas para os estudantes, pois contribuíram para a sua formação tendo a oportunidade de se apropriar do conhecimento químico, de forma mais atrativa do que normalmente é visto nas escolas.

Imagem 1: Atividade com jogos didáticos. Fonte: Própria

Imagem 2: Atividade Experimental. Fonte: Própria
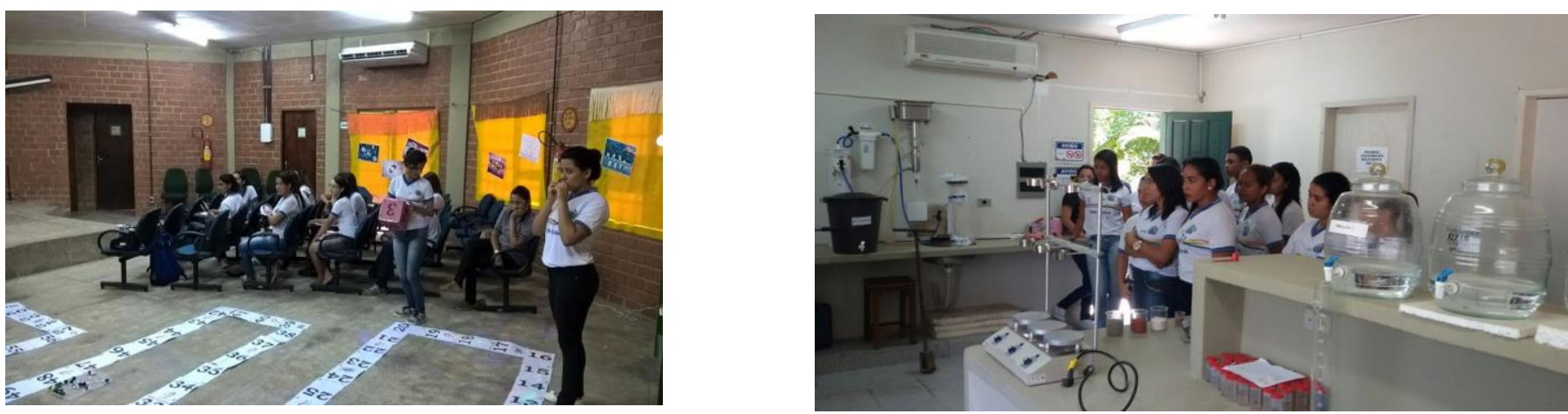

\section{Considerações}

A experiência vivenciada foi bastante proveitosa, não só para os estudantes, mas também para os licenciandos, pois tivemos a oportunidade de trabalharmos algo diferente relacionado a nossa futura área profissional. Diante disso, além de despertarmos o interesse dos estudantes que participaram da visita guiada para o curso de licenciatura em Química, pelo fato de vermos os estudantes encantados por algo que fará parte da nossa rotina enquanto futuros professores de Química, também nos sentimos despertados.

Destacamos a importância das instituições parceiras do PDVL replicarem esse tipo de atividade para então alcançarmos o objetivo geral do programa para então superarmos o déficit de professores com formação em Química atuando nas salas de aula do Ensino Médio da Educação Básica de Ensino.

\section{Referências}

BRASIL. Estudo exploratório sobre o professor brasileiro 2009. Disponível em: <http://portal.mec.gov.br/basica/censo/Escolar/sinopse/sinopse.asp> Acesso em 02 out. de 2016. 